\title{
A Simple Classroom Experiment on Money Demand
}

\author{
Xiaofen Chen \\ Truman State University \\ xiaofen@truman.edu
}

\begin{abstract}
This simple classroom experiment is designed to help students to better understand the concept and the theory of money demand. By simulating what households face in real life, the experiment allows students to reflect on the cost and benefit of holding money and understand how money demand is affected by various factors. The experiment is suitable for an undergraduate macroeconomics course at the introductory or intermediate level. The paper also presents evidence of effectiveness of the experiment on student learning, controlling for student characteristics. Stronger effects are found for lower-year students, native English speakers, students with better attendance, and those with lower GPAs.
\end{abstract}

Key words: money demand, macroeconomic experiment, classroom experiment effect, economic education

\section{Introduction}

Money demand is a key concept in introductory and intermediate macroeconomics. It is at the core of models based on the money market, such as the short-run models (including the conventional IS-LM model and the more recent IS-MP model) and the open economy macroeconomic models adopted in international economics textbooks (for example, the Mundell-Fleming model and Dornbusch's overshooting model). However, students often confuse it with other concepts, such as money supply, saving, income, and wealth, causing difficulties in understanding subsequent theories.

The purpose of this paper is twofold. First, it introduces a classroom experiment to illustrate the concept of money demand. By simulating what households face in real life, the experiment gives students an opportunity to reflect on the cost and benefit of holding money and better understand how money demand is affected by expenditure, interest rate, and the cost of transferring financial assets to money. The expanded version of the model can also incorporate factors such as interest rate and exchange rate risks. Suggested issues for follow-up discussion and questions for a homework assignment based on the experiment data are included to further reinforce students' learning experience. The second purpose of the paper is to examine the resulting student learning outcome so that instructors are aware how successful the experiment is during trial. Using data collected from multiple sections of macroeconomics courses at the principles and intermediate levels, the paper finds a strong, positive effect of the experiment, controlling for student characteristics.

In general, existing literature on classroom experiments is either a description of a new classroom experiment (for example, Hodgson, 2014; Ewing, Kruse, \& Thompson, 2004) or a study of the effectiveness of existing experiments (for example, Emerson \& Taylor, 2004; Eisenkopf \& 
Sulser, 2013), but not both. ${ }^{1}$ This paper introduces a new classroom experiment concerning a macroeconomic concept and adds to the pool of classroom experiments in macroeconomics that is still relatively small. In addition, by studying the resulting student learning outcome, this paper takes it to the next level to present evidence of efficacy of the experiment so that instructors are better informed before adopting it. The study will also contribute to the general understanding of the effectiveness of classroom experiments in association with student characteristics.

Although the growing popularity of adopting classroom experiments as a teaching strategy indicates favorable opinions among instructors, the results of existing formal studies vary widely on the effectiveness of classroom experiments. A closer look at these studies reveals that the existing studies differ in the experiments used, the measures of student learning, and the approaches to draw conclusions. As a result, their results may not be entirely comparable. First, the experiments used in the studies are different, rendering cross-study comparison and generalization of results from individual studies problematic, particularly for those based on a single experiment. The size and characteristics of students involved also vary greatly. For example, Gremmen and Potters (1997) used a simulation of international economic relations in three college-level classes with 47 students in total. Without controlling for student characteristics, they found the effect of the game was positive immediately after it was conducted, but it dissipated over time. Eisenkopf and Sulser (2013) studied a fishing game with 42 classes of 720 high school students, and found the effect of the game strongly depended on student capabilities. Other studies also confirmed that the gains from classroom experiments may be affected by classroom size, preferences of learning styles (Durham, McKinnon, \& Schulman, 2007), whether incentives are provided (Dickie, 2006), whether a follow-up report is required (Cartwright \& Stepanova, 2012), and so on. Thus, in addition to the quality of individual experiments, the effectiveness of experiments may also depend on student attributes and how they are conducted.

The measure of student learning outcome used in the studies includes test results, student opinions, student attitude, retention of knowledge, etc. Although related, these measures have different emphases and are not perfectly substitutable. When measured by test results, most studies find that classroom experiments yield positive effects on student learning (Eisenkopf \& Sulser, 2013; Emerson \& Taylor, 2004; Frank, 1997; Gremmen \& Potters, 1997), but some studies detected little evidence of test improvement with certain experiments (Durham et al., 2007) or as a general strategy in comparison with the conventional approach (Mitchell, 2008; Yandell, 2004), perhaps due to the aforementioned differences in the research design. Using non-test based measures, Durham, McKinnon, and Schulman (2007) conclude that classroom experiments significantly improve students' attitude toward economics and retention of knowledge, but Emerson and Taylor (2004) find no effect on student evaluations and class attrition rates. For ease of measurement and the benefit of objectivity, this paper uses test performance as a measure of student learning.

The experiment presented in this paper is related to but differs from two existing experiments designed by Beckman (1987) and Ewing et al. (2004). Beckman (1987) describes a SAS computer program based on Baumol (1952) and Tobin (1956), in which participants decide their money demand by buying and selling bonds in a 12-month period, and one such transaction is allowed each month. It takes little time to run with computers, but otherwise it would be too complex and time consuming to run. In Ewing et al. (2004), an interesting experiment is presented focusing on the portfolio theory and stresses the risk factor of assets. However, it does not address

\footnotetext{
${ }^{1}$ The Journal of Economic Education suggests that manuscripts on classroom experiments are divided into these two separate categories (Emerson, 2014). Journal of the Scholarship of Teaching and Learning, Vol. 18, No. 1, January 2018. josotl.indiana.edu 
other fundamental factors, such as interest rates and expenditure, which serve as the foundation of macroeconomic models in macroeconomics and international economics textbooks.

The experiment is based on a model by Baumol and Tobin (1989), which is incorporated in some macroeconomics textbooks (see, for example, Mankiw, 2010; Rossana, 2011). The model serves as a microeconomic foundation for the theory of money demand. It illustrates the transactional motive of holding money and the trade-off with holding non-money assets. It also addresses the more recent understanding of the impact of banking deregulation and technological development by considering the cost of transferring non-money assets to money. However, like its alternatives, the model has its limitations. For example, it does not explain the roles of uncertainty and expectation as in some portfolio theories. Of course, it can be impractical to combine different models into a single classroom experiment and attempt to address too many factors. Nevertheless, an expanded version of the experiment accommodating interest rate and exchange rate risks is described later.

The experiment is suitable for an undergraduate macroeconomics course at the introductory or intermediate level. It has a much simpler setting than Beckman's (1987) and only requires paper and pencil to run. The set-up also allows multiple money transactions within a month without a limit, and thus it is more flexible and realistic. It is simple to conduct and flexible enough to allow the instructor to allocate as short as 25 minutes or as long as 50 minutes to finish, with some time left for discussion. Depending on how much time the instructor is willing to spend and how large the class size is, the experiment can be conducted by groups or by individuals. If the class size is large, students can be divided into groups so that entering data will not consume too much time, particularly if the instructor chooses to analyze the results in class immediately after the experiment. Another advantage of having students work in groups is to allow discussions during the experiment before the instructor-led discussion after the experiment.

The experiment does not require computers. However, it will be advantageous if the instructor has a computer and a data projector, since the results can be recorded in a spreadsheet ${ }^{2}$ and aggregate data can be shown and analyzed immediately after the experiment. This will facilitate discussion while students' memories are still fresh. Alternatively, data can be processed by hand with the help of an assistant. The aggregate data can then be shown on the blackboard for discussion.

The remainder of the paper is structured as follows. The first two sections describe the experiment, discuss the experiment results based on my experience, and offer suggestions on inclass discussion and homework assignment. The third section contains suggestions on how the experiment can be run in alternative ways, incorporating additional factors such as interest rate and exchange rate risks. The next section presents a formal analysis of student learning outcomes resulting from the experiment. The last section includes final remarks. Instructions, decision recording forms, and sample results from running this experiment are in the Appendices.

\section{Description of the Experiment}

\section{Structure of the Experiment}

${ }^{2}$ An Excel file containing the formulas is available on request. Journal of the Scholarship of Teaching and Learning, Vol. 18, No. 1, January 2018. josotl.indiana.edu 
In the experiment, each student (or group of students) represents a household and makes decisions regarding how much money (cash and checkable deposits, assuming for simplicity that savings deposits are non-money assets) to hold by withdrawing from their savings accounts during a month. Students are given the information regarding: (i) the initial savings deposits at the beginning of the month; (ii) spending level during the month; (iii) interest rate level; and (iv) the cost of making a withdrawal. Savings deposits yield interest, which is calculated based on average balances. Checkable deposits do not bear interest and are treated as cash. Students make withdrawals to pay for spending, which spreads evenly through the month. Each withdrawal incurs a fixed cost regardless of the amount withdrawn and for simplicity's sake it must be in the same amount. Thus, the key decision is how many withdrawals to make during a month and in what amount.

Observed from past results of running this experiment, students can easily see that they should hold just enough money to pay for the spending and not carry a money balance at the end of the month. Thus, for simplicity, I will focus on the experiment in which the number of withdrawals is the only decision to make, and the amount of each withdrawal is the spending level divided by the number of withdrawals. ${ }^{3}$

Payoffs are calculated by subtracting total withdrawing cost from interest earned. The experiment is repeated with different interest rate levels, withdrawing costs, or spending levels. The concept of money demand is illustrated when students consider how they allocate their assets between savings deposits and money (cash and checkable deposits) by weighing the cost (forgone interest earnings) and benefit (convenience, reflected by lower total withdrawing cost) of holding money.

The experiment is repeated 9 times ( 3 quarters with 3 months in each quarter) in total. For simplicity, each month is independent of each other, and an earlier decision does not affect the later months. In the first quarter, the interest rate is different in each month, while the initial savings deposit, spending level, and withdrawing cost are all the same. Thus, students' response in the first quarter will show how their money demand responds to interest rate changes. In the second quarter, the withdrawing cost is lower than in the first quarter (but the same across the three months); everything else follows the first quarter. By comparing the first and second quarters, we can see how money demand changes when the cost of withdrawing money (or converting non-money assets to money) drops. In the third quarter, the spending level is higher than in the first two quarters (but again, it is the same for all the three months in the third quarter). Other conditions are the same as in the second quarter. The change of money demand between these two quarters shows how it is affected by expenditure.

\section{Preparations for and Running the Experiment}

Before the experiment, it is useful to briefly review the concept of money in class: for example, the functions of money and the meaning of each function; the connections between the functions of money and money demand; the measure of money (what is considered as money); and misunderstandings about this concept (perhaps asking students to make a sentence containing the word money and diagnose if the concept in the sentence is the same as defined in macroeconomics). For a principles course, this experiment can be run after finishing the introduction of the money

\footnotetext{
${ }^{3}$ Of course, if there is enough time, this setting can be easily modified to allow the amount withdrawn as part of the decision. See Appendix II for a modified decision recording table. 
concept. For an intermediate level course, spending 10 minutes reviewing the concept should be sufficient.

As in the general case of classroom experiments, it is necessary for the instructor to prepare a handout of detailed instructions and carefully go through them before the experiment. It is essential for the instructions to contain a numerical example to show how payoffs are calculated (see Appendix I). Before the experiment starts, the instructor should ensure that students fully understand what decisions they are expected to make and how their payoffs are calculated. When going through the instructions, it is also beneficial for the instructor to verbally stress some of the information that might be confusing to them: for example, the purpose of the experiment is to illustrate what affects money demand and how each month is independent of each other; savings deposits always start at the same level regardless of previous decisions; their key decision is the number of withdrawals and in which column of the decision table it is recorded; and they can use intuition to make decisions without doing the calculations, and so on.

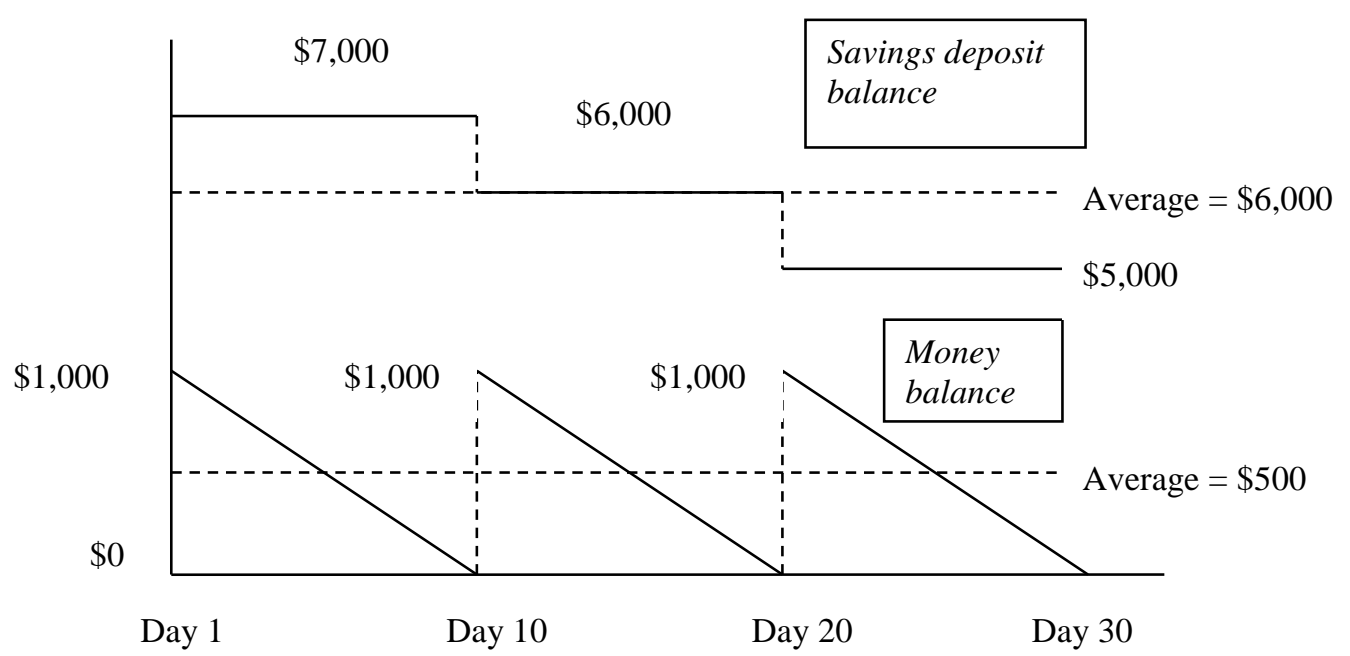

Figure 1. Calculating average balances.

To help students understand how withdrawing decisions affect money balances and payoffs, a graph can be used to illustrate how average money balance and average savings deposits are calculated (Figure 1). This graph is similar to Baumol and Tobin (1989) and Mankiw (2010). Using the example (as in the instructions) of \$8,000 initial savings deposits, \$3,000 monthly spending, and withdrawing 3 times during the month with $\$ 1,000$ per withdrawal, the graph illustrates how money balance and savings deposits change over time during the month. As can be seen, the average money balance in this month is the average of the amount of each withdrawal and \$0 (here it is $(\$ 1,000) / 2=\$ 500)$. Likewise, the average balance of savings deposits is the average of the beginning balance and the ending balance $(\$ 7,000+\$ 5,000) / 2=\$ 6,000$ here $)$. Of course, this chart can also be included in the instruction sheet.

After reviewing the instructions, the instructor can assign a household id to each student for follow-up analysis. The instructor will also point out that students with top total payoffs are awarded extra credit points or small gifts as an incentive. If the monetary value of the maximum payoff in the experiment is small, the instructor can directly use cash as the award. In the past, I have used chocolate bars, candies, small stationery items, such as white-out tapes and post-it notes. 
Even if the values of those items are small, it seems they are more effective in drawing interests from the students than extra credit points.

The instructor may choose to provide the information month by month or simply announce the start and the end of each month to synchronize the pace. However, in my experience, it is preferable to give the information of the 9 months to students all at once, and leave the students to determine the pace by themselves. Providing the information all at once allows the students to more easily compare the differences in the conditions they need to consider and to vary their decisions accordingly. Moreover, even if the calculations are simple and the formulas are included in the table, the pace at which the students complete the first several decisions varies greatly. However, the instructor does need to stress how much time in total they have before the experiment and to frequently remind them about how much remaining time there is during the experiment. The instructor needs to remind the students towards the end of the experiment that if they have not finished making decisions, they must do so using their intuitions without doing the calculations. This will ensure that the experiment is finished on time.

My time allocation of the experiment is usually as follows: 10 minutes for the instructions, 15 minutes for the experiment, and 5-8 minutes for in-class results recording (with 30 students or less). The total time of running the experiment is about 30 minutes.

It is helpful for the instructor to calculate the best number of withdrawals before the experiment in order to choose the appropriate levels of interest rates, expenditure, and withdrawing cost for each case, so that the optimum numbers of withdrawals differ in each case. Using $Y$ to represent spending, $r$ monthly interest rate, $c$ withdrawing cost, and $n$ number of withdrawals, the payoff $\pi=$ (savings deposits $-(Y / n+Y) / 2) * r-n C$. Maximizing $\pi$ yields the optimum $n$ to be the square root of $(\mathrm{Yr} / 2 \mathrm{C})$. However, note that the purpose of the experiment is not to mathematically formulate the maximization problem and find the solution, but to train students to better understand the concepts and the factors determining money demand in an intuitive way.

\section{Decision Recording}

Students record their decisions and calculate money demand and payoffs for each month in a table. Students can make withdrawing decisions intuitively and calculations of payoffs by themselves are not necessary. In this case, the instructor can act as the bank for the households and calculate payoffs for the students. However, it would still be better to include the full version of the decision recording table, while specifying in the instructions that the instructor will perform the final calculations and students should focus on making withdrawing decisions (see experiment instructions in Appendix I). In this case, most students will still choose to perform the calculations for at least their first several decisions since doing the calculations obviously helps their decision making. However, the correctness of their calculations is no longer a concern, and those who struggle can choose to rely on their intuition.

Not requiring calculating payoffs by the students has a number of benefits. First, it ensures that students' effort is focused on making withdrawing decisions, not to calculate the payoffs correctly. Second, students are more likely to try to think intuitively, without having to finish all the calculations. Third, it saves time and removes frustrations students may have due to their fear of mathematics. I have run the experiment with and without requiring payoff calculations, the results (how total money demand of all households change with the factors considered) have not differed greatly. But when it was not specified that calculating the payoffs was not required, there were always a few students who spent too much time in getting the math right and could not focus 
on or finish making decisions. The experiment was also run a few times without including payoffs in the decision recording table and students had to make their decisions based on intuition only. The experiment results still coincided with the theory well.

At the end of the experiment, students report their decisions to the instructor. With a smaller class size, the results can be recorded immediately in class. With a larger class size, the results can be collected and recorded after class. I usually record the results in an Excel table in class (it takes about 5-8 minutes with 20-30 students). The Excel table is pre-designed with all necessary formulas included so that when the number of withdrawals is entered, all corresponding values (monthly average money balance, monthly average balance of savings deposits, interest earnings, total withdrawing cost, and total profit) will be shown. A data projector can be used to display the table while each student reports his or her decision. Students are usually excited to watch and compare each other's payoffs. When there is more time left, the instructor can then proceed to discuss the results of the experiment.

\section{Experiment Results and Follow-up Discussion and Assignments}

I have run the experiment with the number of students ranging between 9 and 38. Individual responses have differed, and the average number of withdrawals and average money demand level may not always turn out to be optimal, especially with a small class. However, most students followed a correct strategy in making their withdrawing decisions, and the aggregate results have always been consistent with the theory, especially in terms of the directions in which money demand changes in response to changes in the factors considered in the experiment. As noted earlier, the purpose of the experiment is not to find the optimal money holding level, but to see what factors affect money demand and how. From my experience, this experiment has served the purpose well. The result of a sample experiment is reported in Appendix III.

As Hazlett (2005) points out, experiments are more effective if students are actively involved in the follow-up analysis. If the data is recorded and processed in class, a preliminary analysis of the data can be done immediately following the experiment. The instructor can randomly ask students why they change their withdrawing decisions in different months, such as why they make more withdrawals in month two, and why they have a lower money balance when the interest rate is higher. In addition, the data can be ordered according to payoffs. The instructor can ask students to compare the strategies of the households with higher and lower payoffs. Specifically, students can analyze why a particular household receives a higher payoff than another household, and recommend strategies for households with lower payoffs.

The following questions can also be discussed in class as an extension:

1) Suppose households can pay for their spending with credit cards. In this case, they write a check and pay the credit card company at the end of the month. How would your decision of withdrawing from your savings deposits be affected?

2) Why does money demand (average money holding) decrease when you withdraw more often? (This question is worth spending time on since students are often confused.)

3) In the real world situation, what are the likely sources of the withdrawing cost? Does your bank charge you when you make a withdrawal from your savings account? How long would it take to make a withdrawal if you have to go to your bank in person and wait in line? How do we measure the value of the time spent on making a withdrawal? What has happened to the withdrawing cost with the use of ATM machines, telephone banking, and internet banking? 
4) Suppose you have a higher initial savings account balance, but your spending level, the withdrawing cost, and interest rates are the same. Would you respond differently?

A homework assignment can follow the experiment. The purpose is to guide students to further summarize the results generalized from the experiment and derive the money demand curve based on the results. The following are some sample questions:

1) What advice would you give to households 2 and 3? How would their money holding change if they follow your advice?

2) Imagine that the households participating in the experiment form a mini-economy.

a. Calculate the aggregate money holding (money demand) for this economy by month.

b. Using the aggregate data for the first quarter, draw a money demand curve with interest rate at the vertical axis and money demand at the horizontal axis. How does money demand change with interest rates? Explain why.

c. In the same graph, repeat part b for the second quarter. How does the position of the money demand curve change? What caused the shift?

d. In the same graph, repeat part c for the third quarter.

e. With monthly income as the sum of total spending for all households, calculate the money demand parameter $k$ and income velocity $V$ (as in the quantity equation) for each month. How have they changed with interest rate, withdrawing cost, and spending level?

\section{Modifications and Expansion of the Experiment}

The experiment uses the narrow definition of money (M1, or cash and checkable deposits). Savings deposits are treated as non-money assets. The experiment can be modified to treat savings deposits as part of a broader definition of money. In this case, non-money assets can be represented by bonds, stocks, or fixed term deposits.

Spending levels can be the same or different across households. If the class size is relatively large, several tiers of spending levels can be assigned to different households. In this case, the experiment does not have to be repeated as many times and the ones illustrating how spending level affects money demand (the third quarter) can be eliminated. The transactional demand for money can be addressed by charting the money demand curve for different spending levels as part of a homework assignment.

Instructors who wish to focus only on the interest rate factor can save time and just use the first 3 months of the experiment. Likewise, to focus on the withdrawing cost only, the experiment can also be reduced to 2 to 3 months, with varying withdrawing costs but the same interest rates and spending levels. An alternative version of the experiment is to divide each month into several periods (for example, 4 weeks). Students decide whether to make a withdrawal in each period, and in what amount if they do. This setting is similar to Beckman (1987) and limits the maximum number of withdrawals each month. The corresponding recording table is in Appendix II.

The experiment can be set up differently to allow for interactions and collaboration between students. Students can be paired with one representing a household, the other a bank. For a visual effect, hand out printouts of hypothetical money totaling the amount of the initial savings deposits to each bank (for example, eight printouts of \$1,000). These initial assets can also be designated as bonds, if instructors so choose, and banks as brokers. For simplicity, each month is divided into 4 weeks with the same conditions. A change in interest rate, withdrawing cost, or spending level is introduced at the beginning of a new month. At the beginning of each week, 
households consult with their banks and make the decision whether to withdraw or not and in what amount. When they make a withdrawal, they receive money from their banks. At the end of the week, households remove an amount equivalent to their weekly spending from their cash holding. Households and banks are each primarily responsible for keeping records of money and savings account balances, respectively. They calculate the profit for the household at the end of the month separately and compare the results with each other to ensure accuracy. The instruction and recording sheet is included in Appendix IV. They are also allowed time to discuss observations after each month. In this setup, it is best to spend more time (about 10 minutes) on the first month to ensure students follow the instructions correctly. The rest of the months take less time to run.

The experiment can also be expanded to incorporate risks of returns on non-money assets. An additional month can be added when the interest rate is uncertain. Following Ewing et al. (2004), the uncertainty can be introduced by flipping a coin, with one side associated with high interest rate and the other side with low interest rate (ideally, a negative interest rate), and the mean the same as the interest rate in the previous month. As an illustration, during the last month in the alternative setup in Appendix IV, interest rate is determined by flipping a coin as either $8 \%$ or $-6 \%$ with the mean $1 \%$. In the baseline experiment, a pair of multipliers can be used to multiply the interest rates in a previous quarter while keeping the means the same, for example, 8 (heads) and -6 (tails). Although simple, this setting also implies that higher returns are associated with higher risks. Thus, comparisons within the 3-month quarter and with a previous quarter when no risk is involved are both worth attention as part of the follow-up discussion.

The effect of exchange rate risk on money demand is more complex. As reviewed by Arize, Malindretos, \& Shwiff (1999), on one hand, the desire to reduce holdings of risky assets may cause demand for domestic money to increase with increased foreign exchange risk (Zilberfarb, 1988); on the other hand, money demand can also decrease due to a greater incentive to diversify assets and offset the higher transaction cost of international trade associated with more uncertain exchange rates (Akhtar \& Putnam, 1980). If instructors wish to illustrate the former, the exchange rate risk can be combined with interest rate risk, specified as uncertainty in returns on interest earning assets. To illustrate the latter, additional periods of the experiment may be introduced (more conveniently to the alternative setup as in Appendix III), in which households spend on both domestic and foreign goods, paid by domestic and foreign currencies, respectively. The conversion from the domestic currency to the foreign currency may be at a fixed rate (without exchange rate risk) or at a variable rate determined by flipping a coin (with exchange rate risk).

\section{Assessment of the Experiment}

To collect evidence that the experiment fosters student learning, I made a few attempts to evaluate the effect when using this experiment in my courses. After reviewing the concept of money and the money demand theory in an abstract way, students were asked to answer four questions on money demand before the experiment. After the experiment, they answered the same questions, and the number of correct answers was compared. Based on the results of two sections of intermediate macroeconomics with 29 students each, on average, students answered 2.0 questions correctly before the experiment and 2.3 questions correctly after the experiment but before any discussion of the results. The mean improvement was 0.34 (17\%) with a significance level of $13 \%$. However, the result improved more significantly after the follow-up discussion and homework assignment (but before the homework was graded). The average number of correct answers increased from 1.9 to 3.4 with a significance level of $7 \%$ in a study with 15 students. This result 
indicates that it is important to use follow-up analysis in order to take full advantage of classroom experiments.

Two short student surveys indicated students' favorable attitude towards the experiment. An anonymous survey was first conducted after the class discussion but before the homework assignment in two classes of intermediate macroeconomics with 58 students in total. The result indicated that $86 \%$ of the students agreed or strongly agreed that the experiment helped them better understand money demand; $71 \%$ agreed or strongly agreed that they had a better understanding of the concept of money; and 84\% would recommend using this experiment for this course in the future. A second anonymous survey was conducted after the follow-up discussion and the homework assignment (but before the homework was graded) in an intermediate macroeconomics class of 15 students; the corresponding proportions of the students who agreed or strongly agreed to the above three statements were $100 \%, 90 \%$, and $90 \%$, respectively.

To further understand if the gains from the experiment differ depending on student characteristics, a more careful assessment was carried out later with students from principles of macroeconomics and intermediate macroeconomics courses. After the usual coverage of the contents on money and money demand, students were randomly divided into an experimental group and a control group, and a test of nine questions on money demand was given to all students. A bonus credit equivalent to $0.6 \%-1.5 \%$ of the total grade was given to participating students. To isolate the effect of the experiment without mixing it with that of homework assignments, the postexperiment test was given without completing a related homework assignment. A survey of student characteristics was also collected. The sample includes 132 students from four sections of Intermediation Macroeconomics and one section of Principles of Macroeconomics across several semesters. Most of the students were majoring in business, only a few were economics majors and minors. As shown in Table 1, the distributions of student characteristics in the two groups are generally similar. The mean improvement in the number of correct questions was about $8 \%$ with a significance level of $1.5 \%$.

Regressions are run with the logarized test score as the dependent variable, while the experiment dummy (which equals 1 if in the experiment group) and student characteristics in Table 1 as explanatory variables. In considering the relatively small sample size, model selection is conducted using several criteria. With the Schwarz Bayesian (BIC) or Akaike information criterion (AIC), only the experiment dummy, GPA, and college year remain as explanatory variables; with the adjusted R-squared criterion, two additional variables, interest in economics and the female dummy are also kept. The regression results of these two models are reported in columns (1) and (2) in Table 2. Interactions between the experiment dummy and other variables are also considered, including those excluded as a result of the model selection process, two of which, the number of classes missed and the dummy for non-native English speaker, are added back due to their significant interaction terms with the experiment dummy. The results including these variables but without the interaction terms are in column (3) and those with the significant interaction terms are in column (4). Finally, column (5) includes an additional interaction term between GPA and the experiment dummy since it is often considered by the literature, even though it is not significant when it is included alone.

Diagnostic tests indicate that the specifications of the models are sound. Take model 3 as an example. The $p$-value is 0.933 for Ramsey's RESET test for functional form and 0.196 for White's test for heteroscedasticity, and there is no sign for collinearity with the variance inflation factors all below 1.3. 
Table 1. Descriptive Statistics

\begin{tabular}{|c|c|c|c|c|c|}
\hline & \multicolumn{3}{|c|}{$\begin{array}{l}\text { Without } \\
\text { experiment }\end{array}$} & \multicolumn{2}{|c|}{ With experiment } \\
\hline & & Mean & $\begin{array}{r}\text { St. } \\
\text { dev. }\end{array}$ & Mean & $\begin{array}{r}\text { St. } \\
\text { dev. }\end{array}$ \\
\hline Number of students & 61 & & & 71 & \\
\hline Principles of Macroeconomics & 11 & & & 9 & \\
\hline Intermediate Macroeconomics & 50 & & & 62 & \\
\hline Female & 34 & & & 34 & \\
\hline Non-native English speaker & 23 & & & 17 & \\
\hline Test score (0-9) & & 4.77 & 1.68 & 5.52 & 1.80 \\
\hline GPA & & 3.31 & 0.43 & 3.28 & 0.49 \\
\hline Interest in economics ( $0=$ none; $3=$ much $)$ & & 1.52 & 0.87 & 1.51 & 0.72 \\
\hline Number of economics courses taken & & 3.62 & 1.79 & 3.54 & 1.16 \\
\hline Number of classes missed for the course & & 0.98 & 1.82 & 1.44 & 2.63 \\
\hline Hours spent studying for the course & & 4.30 & 3.28 & 4.20 & 2.70 \\
\hline College year (1-4) & & 2.79 & 0.78 & 2.70 & 0.92 \\
\hline
\end{tabular}

Estimation of the effect of the experiment dummy is stable and highly significant across all regressions. Similar to the regressions without interaction terms, the average marginal effect of the experiment dummy is 0.19 in the regressions with the interaction terms (models 4 and 5). These results indicate an 18-20\% marginal improvement in test scores after the experiment. Among other variables, GPA, an indicator of aptitude, is consistently highly significant, as in the literature (for example, Durham et al., 2007).

The results for the interaction terms suggest that the benefit of the experiment is substantially more for lower-year students, native English speakers, those who do not tend to miss classes, and those who have lower GPAs. Perhaps classroom experiments are particularly helpful for those who are less academically mature, indicated by their lower GPAs or shorter attendance in college. On the other hand, those who have missed many classes may lack the preparations or the desire to learn from the experiment. Different life experiences and the challenge of the English language may also create a hurdle for non-native English speakers to absorb the implications of the experiment in a short time.

The interaction terms of the experiment dummy with all other variables are insignificant (not shown in the table), and there is no compelling evidence that other student characteristics, such as interest, previous exposure to economics, and gender, play a role in test scores or gains from the experiment. As an example, unlike in Durham et al. (2007) and Emerson \& Taylor (2004), neither the main effect of the female dummy, nor its interaction with the experiment dummy, which has a $p$-value of 0.664 when added to model 5 , indicates any gender difference on test performance or the effect of the experiment.

\section{Table 2. Regression Results (p-values in parentheses)}




\begin{tabular}{|c|c|c|c|c|c|}
\hline & $(1)$ & $(2)$ & $(3)$ & $(4)$ & $(5)$ \\
\hline Experiment & $\begin{array}{l}0.184 * * * \\
(0.002)\end{array}$ & $\begin{array}{l}0.204^{* * *} \\
(0.001)\end{array}$ & $\begin{array}{l}0.201 * * * \\
(0.001)\end{array}$ & $\begin{array}{l}0.973^{* * *} \\
(0.000)\end{array}$ & $\begin{array}{l}2.206 * * * \\
(0.000)\end{array}$ \\
\hline GPA & $\begin{array}{l}0.320 * * * \\
(0.000)\end{array}$ & $\begin{array}{l}0.281 * * * \\
(0.000)\end{array}$ & $\begin{array}{l}0.287 * * * \\
(0.000)\end{array}$ & $\begin{array}{l}0.365 * * * \\
(0.000)\end{array}$ & $\begin{array}{l}0.590 * * * \\
(0.000)\end{array}$ \\
\hline College year & $\begin{array}{l}0.111^{* * *} \\
(0.002)\end{array}$ & $\begin{array}{l}0.112 * * * \\
(0.002)\end{array}$ & $\begin{array}{l}0.111^{* * *} \\
(0.003)\end{array}$ & $\begin{array}{l}0.248^{* * *} \\
(0.000)\end{array}$ & $\begin{array}{l}0.297 * * * \\
(0.000)\end{array}$ \\
\hline Interest in economics & - & $\begin{array}{l}0.058 \\
(0.154)\end{array}$ & $\begin{array}{l}0.059 \\
(0.153)\end{array}$ & $\begin{array}{l}0.045 \\
(0.252)\end{array}$ & $\begin{array}{l}0.047 \\
(0.223)\end{array}$ \\
\hline Female & - & $\begin{array}{l}0.080 \\
(0.218)\end{array}$ & $\begin{array}{l}0.084 \\
(0.211)\end{array}$ & $\begin{array}{l}0.078 \\
(0.215)\end{array}$ & $\begin{array}{l}0.072 \\
(0.243)\end{array}$ \\
\hline Non-native English speaker & - & - & $\begin{array}{l}-0.004 \\
(0.952)\end{array}$ & $\begin{array}{l}0.121 \\
(0.160)\end{array}$ & $\begin{array}{l}0.156^{*} \\
(0.073)\end{array}$ \\
\hline Number of classes missed & - & - & $\begin{array}{l}0.0048 \\
(0.729)\end{array}$ & $\begin{array}{l}0.052 * * \\
(0.032)\end{array}$ & $\begin{array}{l}0.074^{* * *} \\
(0.005)\end{array}$ \\
\hline Experiment $*$ college year & - & - & - & $\begin{array}{l}-0.228 * * * \\
(0.001)\end{array}$ & $\begin{array}{l}-0.279 * * * \\
(0.000)\end{array}$ \\
\hline $\begin{array}{l}\text { Experiment } * \\
\text { non-native English speaker }\end{array}$ & - & - & - & $\begin{array}{l}-0.304^{* *} \\
(0.019)\end{array}$ & $\begin{array}{l}-0.343 * * * \\
(0.008)\end{array}$ \\
\hline $\begin{array}{l}\text { Experiment } * \\
\text { Number of classes missed }\end{array}$ & - & - & - & $\begin{array}{l}-0.0549 * \\
(0.051)\end{array}$ & $\begin{array}{l}-0.081 * * * \\
(0.008)\end{array}$ \\
\hline Experiment * GPA & - & - & - & - & $\begin{array}{l}-0.318^{* *} \\
(0.034)\end{array}$ \\
\hline Constant & $\begin{array}{l}0.12 \\
(0.650)\end{array}$ & $\begin{array}{l}0.115 \\
(0.669)\end{array}$ & $\begin{array}{l}0.092 \\
(0.750)\end{array}$ & $\begin{array}{l}-0.620 * \\
(0.055)\end{array}$ & $\begin{array}{l}-1.534 * * * \\
(0.004)\end{array}$ \\
\hline
\end{tabular}

\section{Final Remarks}

As Ewing et al. (2004) note, existing experiments are mainly designed for teaching microeconomics and few are for macroeconomics. However, macroeconomics probably requires more abstract thinking since it may be more difficult for students to relate to their personal experience when studying macroeconomics. The theory of money demand is the key to understand a host of macroeconomic theories currently taught at the college level. Although a difficult and 
confusing topic, it has a well-established microeconomic foundation, making it a perfect candidate for classroom experiments. ${ }^{4}$

One benefit of using classroom experiments is the promotion of knowledge retention (Parker, 1995). The decision-making process in this experiment enables students to better remember the material, particularly if the instructor guides the students to derive the intended theoretical results through follow-up analyses. Using the experiment in principles of macroeconomics and intermediate macroeconomics courses, I found that students had a more thorough understanding of money demand when they were subsequently introduced to related theories. However, such observations may be subjective and difficult to measure, as pointed out by Holt and McDaniel (1998). Studies may be designed to test whether experiments improve knowledge retention and aid learning of related theories.

The formal analysis of the effect of the experiment presented in this paper shows strong evidence that the experiment has a positive effect on student learning, and the effect is stronger for lower-year students, native English speakers, students with better attendance, and those with lower GPAs. However, there is no evidence that other student characteristics, including gender, affect test performance or the gains from the experiment.

The positive effect of the experiment in this paper is measured without a follow-up assignment, and the evidence that student learning can further improve after completing an assignment is preliminary. Further assessment may be carried out to compare the outcome after an assignment is complete. As in the literature, indicators other than test scores, such as improvement in student interest and attitudes towards economics, may also be used to measure student learning outcome.

\footnotetext{
${ }^{4}$ See Hazlett (2006) and Parker (1995) for suggestions on choosing experiments. Journal of the Scholarship of Teaching and Learning, Vol. 18, No. 1, January 2018. josotl.indiana.edu
} 


\section{Appendices}

\section{Appendix I. Instructions and Decision Recording Table}

\section{Instructions}

1. In this activity, each of you represents a household. You will determine your money demand level for each of the nine months considered. Your purpose is to keep enough money (including cash and checkable deposits) for your household's spending needs by withdrawing from your savings account and earn as much profit as possible. Your profit is your interest earnings less your total withdrawing cost.

2. You have $\$ 8,000$ initial deposit in your savings account at the beginning of each month. You earn interests on your savings deposits. Your interest earning is calculated based on the average balance of your savings account.

3. Your monthly spending is distributed evenly through the month. You pay for your spending with money (in cash or checkable deposits) by withdrawing from your savings account. There is no initial money balance. For simplicity, each withdrawal is in the same amount and just enough for your spending. For example, if your spending is \$2,000, and you make 2 withdrawals, each withdrawal is $\$ 1,000$. The first withdrawal always occurs at the beginning of the month, and the rest spreads evenly through the month. Each withdrawal incurs a cost, which will be specified later. Money does not bear interest.

4. The following is an example of how your profit is calculated.

\begin{tabular}{|c|c|c|c|c|c|c|c|c|c|c|}
\hline Month & $\begin{array}{l}\text { Monthly } \\
\text { spending }\end{array}$ & $\begin{array}{l}\text { Monthly } \\
\text { interest } \\
\text { rate }\end{array}$ & $\begin{array}{l}\text { Cost per } \\
\text { withdrawal }\end{array}$ & $\begin{array}{l}\text { Number of } \\
\text { withdrawals } \\
\text { (key } \\
\text { decision) }\end{array}$ & $\begin{array}{l}\text { Amount per } \\
\text { withdrawal }\end{array}$ & $\begin{array}{l}\text { Average } \\
\text { cash/checking } \\
\text { account balance } \\
\text { (money demand) }\end{array}$ & $\begin{array}{l}\text { Average savings } \\
\text { account balance }\end{array}$ & $\begin{array}{l}\text { Interest } \\
\text { earned }\end{array}$ & $\begin{array}{l}\text { Total } \\
\text { withdrawin } \\
\text { g cost }\end{array}$ & Profit \\
\hline & $y$ & $i$ & $F$ & $(1)$ & $(2)=y /(1)$ & $(3)=(2) / 2$ & $\begin{array}{l}(4)= \\
\frac{(8000-(2))+(8000-}{2}\end{array}$ & $\begin{array}{l}\text { (5) }= \\
(4) * i\end{array}$ & $\begin{array}{c}(6)= \\
F *(1)\end{array}$ & $\begin{array}{l}(7)= \\
(5)-(6)\end{array}$ \\
\hline $\begin{array}{l}\text { Month } \\
\mathrm{x}\end{array}$ & $\$ 3,000$ & $0.4 \%$ & $\$ 3$ & 3 & $\begin{array}{l}\$ 3,000 / 3= \\
\$ 1,000\end{array}$ & $\$ 1,000 / 2=\$ 500$ & $\begin{array}{l}=(\$ 7,000+ \\
\$ 5,000) / 2 \\
=\$ 6,000\end{array}$ & $\begin{array}{l}\$ 6,000 * \\
0.4 \% \\
=\$ 24\end{array}$ & $\$ 3 * 3=\$ 9$ & $\begin{array}{l}\$ 24-\$ 9 \\
=\$ 15\end{array}$ \\
\hline
\end{tabular}

5. Next, you will determine your money demand level through your withdrawing decisions in each of the nine months considered. Each month is independent of each other so your decision does not affect the conditions of the later months. In the first three months, your monthly spending and the cost of each withdrawal are the same, but interest rate differs. In the second quarter, the cost of each Journal of the Scholarship of Teaching and Learning, Vol. 18, No. 1, January 2018. josotl.indiana.edu 
withdrawal is lower; everything else is the same as in the first quarter. In the third quarter, your spending level is higher; everything else follows the $2^{\text {nd }}$ quarter. Note that your key decision is how many times you withdraw each month, recorded in column (1). You may use your intuition to make the decisions and do not have to fill out columns (2)-(7). At the end of the activity, you will report this decision (column (1)) to me, and I will act as your bank and calculate your average balances and profit (again assuming you do not keep more money than necessary). The household with the highest total profit will receive a reward from me.

\section{Decision Recording Table}

You start with \$8,000 savings deposits and no money balance at the beginning of each month.

\begin{tabular}{|c|c|c|c|c|c|c|c|c|c|c|}
\hline Month & $\begin{array}{l}\text { Monthly } \\
\text { spending }\end{array}$ & $\begin{array}{l}\text { Monthly } \\
\text { interest } \\
\text { rate }\end{array}$ & $\begin{array}{l}\text { Cost per } \\
\text { withdrawal }\end{array}$ & $\begin{array}{l}\text { Number of } \\
\text { withdrawals } \\
\text { (key } \\
\text { decision) }\end{array}$ & $\begin{array}{l}\text { Amount } \\
\text { per } \\
\text { withdrawal }\end{array}$ & $\begin{array}{l}\text { Average } \\
\text { cash/checking } \\
\text { account balance } \\
\text { (money demand) }\end{array}$ & $\begin{array}{l}\text { Average savings } \\
\text { account balance }\end{array}$ & $\begin{array}{l}\text { Interest } \\
\text { earned }\end{array}$ & $\begin{array}{l}\text { Total } \\
\text { withdrawing } \\
\text { cost }\end{array}$ & Profit \\
\hline & $y$ & $i$ & $F$ & $(1)$ & $\begin{array}{l}(2)=y / \\
(1)\end{array}$ & $(3)=(2) / 2$ & $\begin{array}{l}(4)= \\
\frac{(8000-(2))+(8000-y)}{2}\end{array}$ & $\begin{array}{l}(5)= \\
(4) * i\end{array}$ & $\begin{array}{c}(6)= \\
F^{*}(1)\end{array}$ & $\begin{array}{l}(7)= \\
(5)-(6)\end{array}$ \\
\hline \multicolumn{11}{|l|}{$1^{\text {st }}$ quarter } \\
\hline Month 1 & $\$ 4,000$ & $0.1 \%$ & $\$ 2$ & & & & & & & \\
\hline 2 & $\$ 4,000$ & $0.6 \%$ & $\$ 2$ & & & & & & & \\
\hline 3 & $\$ 4,000$ & $1.2 \%$ & $\$ 2$ & & & & & & & \\
\hline \multicolumn{11}{|l|}{$2^{\text {nd }}$ quarter } \\
\hline Month 4 & $\$ 4,000$ & $0.1 \%$ & $\$ 0.2$ & & & & & & & \\
\hline 5 & $\$ 4,000$ & $0.6 \%$ & $\$ 0.2$ & & & & & & & \\
\hline 6 & $\$ 4,000$ & $1.2 \%$ & $\$ 0.2$ & & & & & & & \\
\hline \multicolumn{11}{|l|}{$3^{\text {rd }}$ quarter } \\
\hline Month 7 & $\$ 7,500$ & $0.1 \%$ & $\$ 0.2$ & & & & & & & \\
\hline 8 & $\$ 7,500$ & $0.6 \%$ & $\$ 0.2$ & & & & & & & \\
\hline 9 & $\$ 7,500$ & $1.2 \%$ & $\$ 0.2$ & & & & & & & \\
\hline
\end{tabular}




\section{Appendix II. Alternative Decision Recording Tables}

a. Decision recording table with amount of each withdrawal as part of the decision

\begin{tabular}{|c|c|c|c|c|c|c|c|c|c|c|}
\hline Month & $\begin{array}{l}\text { Monthly } \\
\text { spending }\end{array}$ & $\begin{array}{l}\text { Monthly } \\
\text { interest } \\
\text { rate }\end{array}$ & $\begin{array}{l}\text { Cost per } \\
\text { withdrawal }\end{array}$ & $\begin{array}{l}\text { Number of } \\
\text { withdrawals } \\
\text { (key } \\
\text { decision) }\end{array}$ & $\begin{array}{l}\text { Amount of } \\
\text { each } \\
\text { withdrawal }\end{array}$ & $\begin{array}{l}\text { Average } \\
\text { cash/checking } \\
\text { account balance } \\
\text { (money demand) }\end{array}$ & $\begin{array}{l}\text { Average savings } \\
\text { account balance }\end{array}$ & $\begin{array}{l}\text { Interest } \\
\text { earned }\end{array}$ & $\begin{array}{l}\text { Total } \\
\text { withdraw- } \\
\text { ing cost }\end{array}$ & Profit \\
\hline & $y$ & $i$ & $F$ & $(1)$ & (2) & $\begin{array}{l}(3)= \\
\frac{(2)+(1) *(2)-\$ 4,000}{2}\end{array}$ & $\begin{array}{l}(4)= \\
\frac{(8000-(2))+(8000-(1) *(2))}{2}\end{array}$ & $\begin{array}{l}(5)= \\
(4) * i\end{array}$ & $\begin{array}{c}(6)= \\
F *(1)\end{array}$ & $\begin{array}{l}(7)= \\
(5)-(6)\end{array}$ \\
\hline $\begin{array}{l}1^{\text {st }} \\
\text { quarter }\end{array}$ & & & & & & & & & & \\
\hline $\begin{array}{l}\text { Month } \\
1\end{array}$ & $\$ 4,000$ & $0.1 \%$ & $\$ 2$ & & & & & & & \\
\hline 2 & $\$ 4,000$ & $0.6 \%$ & $\$ 2$ & & & & & & & \\
\hline 3 & $\$ 4,000$ & $1.2 \%$ & $\$ 2$ & & & & & & & \\
\hline
\end{tabular}

b. Decision recording table for an example month when each month is divided to 4 periods.

\begin{tabular}{|c|c|c|c|c|c|c|c|c|c|c|}
\hline & \multirow{2}{*}{$\begin{array}{l}\text { Amount } \\
\text { withdrawn }\end{array}$} & \multirow{2}{*}{$\begin{array}{l}\text { Withdrawing } \\
\text { cost } \\
\text { (\$0 if no } \\
\text { withdrawal) }\end{array}$} & \multirow{2}{*}{$\begin{array}{l}\text { Savings } \\
\text { account } \\
\text { balance }\end{array}$} & \multicolumn{2}{|c|}{ Money holding } & \multirow{2}{*}{$\begin{array}{l}\text { Average } \\
\text { money } \\
\text { holding }\end{array}$} & \multirow{2}{*}{$\begin{array}{l}\text { Interest } \\
\text { earned }\end{array}$} & \multirow[t]{2}{*}{ Profit } & \multirow{2}{*}{$\begin{array}{l}\text { Total profit } \\
\text { for all } \\
\text { periods }\end{array}$} & \multirow{2}{*}{$\begin{array}{l}\text { Money demand } \\
\text { (Average money } \\
\text { holding for both } \\
\text { periods) }\end{array}$} \\
\hline & & & & $\begin{array}{l}\text { Beginning } \\
\text { balance }\end{array}$ & $\begin{array}{l}\text { Ending } \\
\text { balance }\end{array}$ & & & & & \\
\hline & (1) & (2) & $\begin{array}{l}(3)= \\
\text { previous } \\
\text { bal. - (1) }\end{array}$ & $\begin{array}{l}(4)= \\
\text { previous } \\
\text { bal. }+(1)\end{array}$ & $\begin{array}{l}(5)= \\
(4)-1,000\end{array}$ & $\begin{array}{l}(6)= \\
\frac{(4)+(5)}{2}\end{array}$ & $\begin{array}{l}(7)= \\
(3)^{*} \mathrm{i}\end{array}$ & $\begin{array}{l}(8)= \\
(7)-(2)\end{array}$ & $\begin{array}{l}(9)=\text { sum of } \\
(8) \text { for all } \\
\text { periods }\end{array}$ & $\begin{array}{l}(10)=\text { avg. of } \\
(6) \text { for all } \\
\text { periods }\end{array}$ \\
\hline Week 1 & & & $\begin{array}{l}\$ 8,000- \\
(1)=\end{array}$ & $\$ 0+(1)=$ & & & & & & \\
\hline \multicolumn{11}{|l|}{ Week 2} \\
\hline \multicolumn{11}{|l|}{ Week 3} \\
\hline Week 4 & & & & & & & & & & \\
\hline
\end{tabular}




\section{Appendix III. Sample Results}

Sample Experiment Results

(51 students in total from two sections of intermediate macroeconomics)

\begin{tabular}{|l|l|l|l|l|}
\hline & $\begin{array}{l}\text { Interest } \\
\text { rates }\end{array}$ & $\begin{array}{l}\text { Optimum number } \\
\text { of withdrawals in } \\
\text { theory }\end{array}$ & $\begin{array}{l}\text { Average number } \\
\text { of withdrawals in } \\
\text { the experiment }\end{array}$ & $\begin{array}{l}\text { Average money } \\
\text { demand in the } \\
\text { experiment }\end{array}$ \\
\hline $\begin{array}{l}\text { First quarter: } \\
\text { Spending }=\$ 4,000 \\
\text { Withdrawing cost }=\$ 2\end{array}$ & $0.1 \%$ & 1.0 & 1.8 & $\$ 1,433$ \\
\cline { 2 - 5 } & $0.6 \%$ & 2.4 & 2.6 & $\$ 1,077$ \\
\cline { 2 - 5 } $\begin{array}{l}\text { Second quarter: } \\
\text { Spending }=\$ 4,000\end{array}$ & $0.1 \%$ & 3.2 & 3.8 & $\$ 929$ \\
\hline Withdrawing cost $=\$ 0.2$ & $0.6 \%$ & 7.7 & 5.0 & $\$ 801$ \\
\cline { 2 - 5 } $\begin{array}{l}\text { Third quarter: } \\
\text { Spending }=\$ 7,500\end{array}$ & $1.2 \%$ & 11.0 & 7.8 & $\$ 500$ \\
\hline Withdrawing cost $=\$ 0.2$ & $0.1 \%$ & 4.3 & 12.1 & $\$ 439$ \\
\cline { 2 - 5 } & $0.6 \%$ & 10.6 & 6.0 & $\$ 1,153$ \\
\hline
\end{tabular}

Sample Experiment Results: Average Household Money Demand

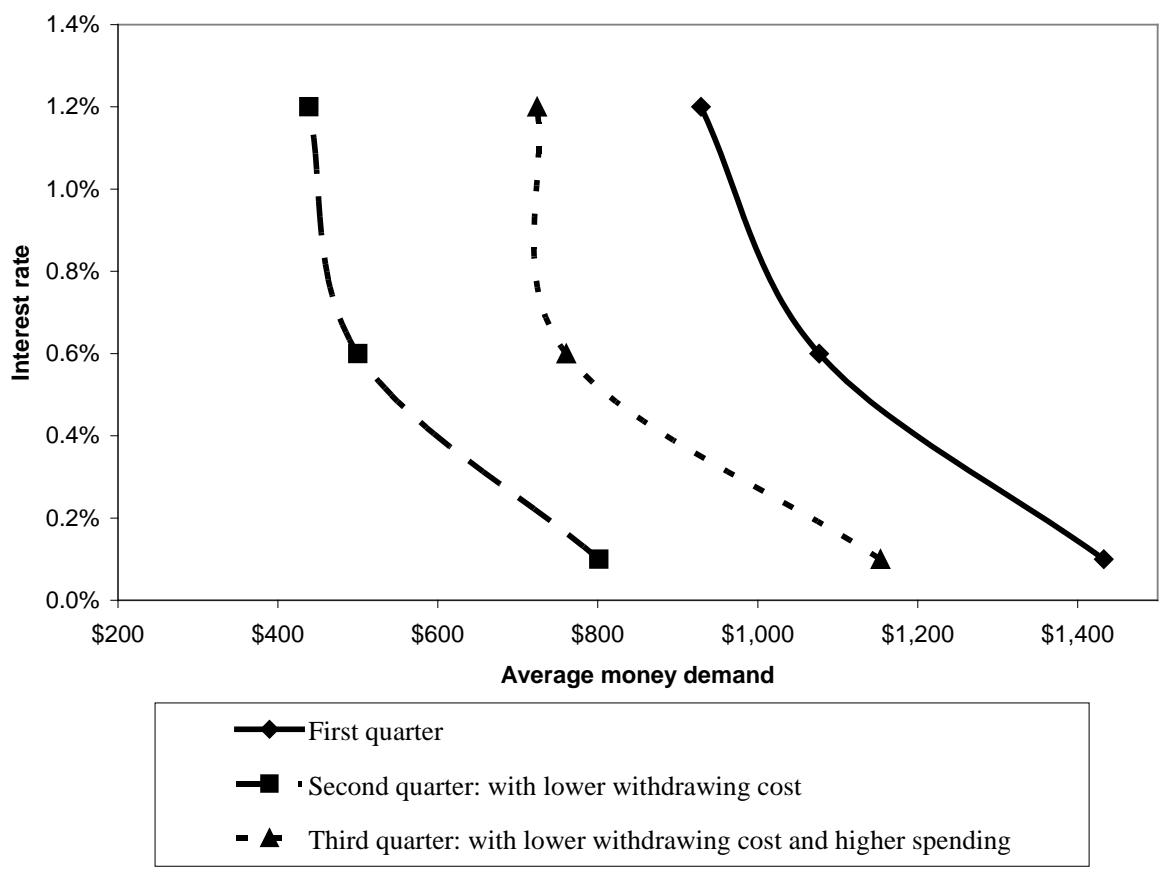

Journal of the Scholarship of Teaching and Learning, Vol. 18, No. 1, January 2018.

josotl.indiana.edu 


\section{Appendix IV. Alternative setup and expansion of the experiment}

1. In this activity, you will pair with another student, one of you representing a household, the other a bank. Households will determine money demand by withdrawing from their savings accounts. The purpose is to keep enough cash for their spending needs and earn as much profit as possible, which equals interest earnings less total withdrawing cost, calculated at the end of the month. The household and the bank are each primarily responsible for keeping records of the household's cash and savings account balances, respectively.

2. Household's spending level, the cost of each withdrawal, and the interest rate for savings deposits will be given at the beginning of each month. Each month consists of 4 weeks. At the beginning of each week, households will decide whether to withdraw, and how much to withdraw from the bank (in $\$ 1,000$ increments). Note that the initial cash balance should be no less than your weekly spending level, or else your monthly profit will be set to zero. At the end of the week, households will remove an amount equivalent to their weekly spending from their cash holding (due to spending). The remaining cash can be spent in later weeks of the same month, but not in later months. I will announce when each week begins and when it ends. Households can consult with their banks and make joint decisions. You may not revise your decision after the end of each week.

\section{Month 1.}

Initial savings account balance: $\$ 8,000$

Interest rate $=0.1 \%$ (that is, every $\$ 1,000$ pays $\$ 1$ interest)

Spending level $=\$ 8,000$

Cost per withdrawal $=\$ 4$

Household's recording table:

\begin{tabular}{|c|c|c|c|c|c|c|}
\hline & \multirow[b]{2}{*}{$\begin{array}{r}\text { Spending } \\
\text { level } \\
\end{array}$} & \multirow[b]{2}{*}{ Withdraw? } & \multirow[b]{2}{*}{$\begin{array}{l}\text { If withdraw, } \\
\text { how much? }\end{array}$} & \multicolumn{3}{|c|}{ Cash (money) balance } \\
\hline & & & & $\begin{array}{r}\text { Beginning } \\
\text { balance }\end{array}$ & $\begin{array}{l}\text { Ending } \\
\text { balance }\end{array}$ & $\begin{array}{l}\text { Average (of } \\
\text { beginning \& } \\
\text { ending bal.) }\end{array}$ \\
\hline week 1 & $\$ 2,000$ & & & & & \\
\hline week 2 & $\$ 2,000$ & & & & & \\
\hline week 3 & $\$ 2,000$ & & & & & \\
\hline week 4 & $\$ 2,000$ & & & & & \\
\hline
\end{tabular}

Your monthly average money holding (money demand) (average of the last column):

Total number of withdrawals:

Total cost of withdrawals $=$ number of withdrawals $* \$ 4=\$$

Your average savings account balance (acquire from your bank):

Your interest earnings $=$ average savings account balance $* 0.001=\$$

Profit $=$ interest earnings - total withdrawing costs $=\$$

Now compare your profit calculation with your bank.

Bank’s recording table (in a separate sheet):

$\begin{array}{r}\begin{array}{c}\text { Spending } \\ \text { level Withdraw? }\end{array} \quad \begin{array}{c}\text { If withdraw, } \\ \text { how much? }\end{array} \text { Savings account remaining balance } \\ \hline\end{array}$

Journal of the Scholarship of Teaching and Learning, Vol. 18, No. 1, January 2018.

josotl.indiana.edu 


\begin{tabular}{cc} 
week 1 & $\$ 2,000$ \\
\hline week 2 & $\$ 2,000$ \\
\hline week 3 & $\$ 2,000$ \\
\hline week 4 & $\$ 2,000$ \\
\hline
\end{tabular}

Total number of withdrawals:

Total cost of withdrawals $=$ number of withdrawals $* \$ 4=\$$

Household's average savings account balance (average of the last column) $=\$$

Household's interest earnings $=$ average savings account balance $* 0.001=\$$

Profit $=$ interest earnings - total withdrawing cost $=\$$

Household's average money holding (money demand) (acquire from household): \$

\section{Month 2.}

Initial savings account balance: $\$ 8,000$

Interest rate $=0.1 \%$ (that is, every $\$ 1,000$ pays $\$ 1$ )

Spending level $=\$ \mathbf{4 , 0 0 0}$

Repeat recording tables.

Cost per withdrawal $=\$ 4$

Discuss 1) if there is any change in the frequency of withdrawals; 2) what the considerations are behind the change; 3) how the change in the frequency of withdrawals affects money holding.

\section{Month 3.}

Initial savings account balance: $\$ 8,000$

Spending level $=\$ 4,000$

Interest rate $=1 \%$ (that is, every $\$ 1,000$ pays $\$ 10$ interest)

Repeat recording tables.

Cost per withdrawal $=\$ 1$

Discuss the causes of any change in average money holding.

\section{Month 4.}

Initial savings account balance: $\$ 8,000$

Interest rate is determined by flipping a coin: $8 \%$ (heads); $-6 \%$ (tails). That is, for every $\mathbf{\$ 1 , 0 0 0}$, you may earn $\mathbf{\$ 8 0}$ or lose $\mathbf{\$ 6 0}$.

Spending level $=\$ 4,000$

Cost per withdrawal $=\$ 1$

Repeat recording tables.

Discuss the causes of any change in average money holding. 


\section{References}

Akhtar, M. A., \& Putnam, B. H. (1980). Money demand and foreign exchange risk: The German case, 1972-1976. Journal of Finance, 35(3), 787-794.

Arize, A. C., Malindretos, J., \& Shwiff, S. S. (1999). Structural breaks, cointegration, and speed of adjustment: Evidence from 12 LDCs money demand. International Review of Economics and Finance, 8(4), 399-420.

Baumol, W. J. (1952). The transaction demand for cash: an inventory theoretic approach. Quarterly Journal of Economics, 66(4), 545-56.

Baumol, W. J., \& Tobin, J. (1989). The optimal cash balance proposition: Maurice Allais' priority. Journal of Economic Literature, 27(3), 1160-62.

Beckman, S. (1987). A microcomputer program that simulates the Baumol-Tobin transactions demand for money. Journal of Economic Education, 18(3), 309-17.

Cartwright, E., \& Stepanova, A. (2012). What do students learn from a classroom experiment: Not much, unless they write a report on it. Journal of Economic Education, 43(1), 48-57.

Dickie, M. (2006). Do classroom experiments increase learning in introductory microeconomics? Journal of Economic Education, 37(3), 267-288.

Durham, Y., McKinnon, T., \& Schulman, C. (2007). Classroom experiments: Not just fun and games. Economic Inquiry, 45(1), 162-178.

Eisenkopf, G., \& Sulser, P. (2013). A randomized controlled trial of teaching methods: Do classroom experiments improve economic education in high schools? Thurgau Institute of Economics Research Paper Series, 80.

Emerson, T. L. N. (2014). Anyone? Anyone? A guide to submissions on classroom experiments. Journal of Economic Education, 45(2), 174-179.

Emerson, T. L. N., \& Taylor, B. A. (2004). Comparing student achievement across experimental and lecture-oriented sections of a principles of microeconomics course. Southern Economic Journal, 70(3), 672-693.

Ewing, B. T., Kruse, J. B., \& Thompson, M. A. (2004). Money demand and risk: A classroom experiment. Journal of Economic Education, 35(3), 243-250.

Frank, B. (1997). The impact of classroom experiments on the learning of economics: An empirical investigation. Economic Inquiry, 35(4), 763-769.

Gremmen, H., \& Potters, J. (1997). Assessing the efficacy of gaming in economic education. Journal of Economic Education, 28(4), 291-303. 
Hazlett, D. (2006). Using classroom experiments to teach economics. In W. E. Becker, M. Watts, \& S. R. Becker (Eds.) Teaching Economics: More Alternatives to Chalk and Talk (pp. 21-38). Northampton, MA: Edward Elgar.

Hodgson, A. (2014). Adverse selection in health insurance markets: A classroom experiment. Journal Economic Education, 45(2), 90-100.

Holt, C. A. and McDaniel, T. (1998). Experimental economics in the classroom. In W. B. Walstad \& P. Saunders (Eds.) Teaching Undergraduate Economics: A handbook for Instructors (pp. 257-268). Boston, London, and Toronto: Irwin/McGraw-Hill.

Mankiw, G. N. (2010). Macroeconomics. $7^{\text {th }}$ edition. New York, NY: Worth.

Mitchell, D. M. (2008). An examination of the impact that classroom based experiments have on learning economic concepts. Journal of Economics (MVEA), 34(1), 21-34.

Parker, J. (1995). Using laboratory experiments to teach introductory economics. Retrieved from http://academic.reed.edu/economics/parker/ExpBook95.pdf.

Rossana, R. J. (2011). Macroeconomics. New York, NY: Routledge.

Tobin, J. (1956). The interest elasticity of demand for cash. Review of Economics and Statistics, 38(3), 241-47.

Yandell, D. (2004). Effects of integration and classroom experiments on student learning and satisfaction. Journal of Economics and Economic Education Research, 5(3), 17-27.

Zilberfarb, B.-Z. (1988). The effects of foreign exchange risk and return on the demand for domestic balances. European Economic Review, 32(6), 1359-68. 